\title{
An Analytical study of Profitability and Operating Ratio analysis of selected Chemical Companies in India
}

\author{
Ahmed Mahdi Abdulkareem ${ }^{1}$, Dr. AlokKumar Chakrawal ${ }^{2}$ \& Kishankumar M.Rathod ${ }^{3}$ \\ ${ }^{1} \mathrm{PhD}$. Research Scholar, Department of Commerce, Saurashtra University, Rajkot, Gujarat - \\ 360005, India \\ ${ }^{2}$ Professor, Department of Commerce and Business Administration, Saurashtra University, \\ Rajkot, Gujarat - 360005, India \\ ${ }^{3}$ Assistant Professor, Satya Prakash College, Rajkot, Gujarat - 360002, India \\ DOI - http://doi.org/10.37502/IJSMR.2021.4805
}

\begin{abstract}
The main purpose of this study is to evaluate the profitability, financial performance and operating position of selected chemical companies in addition to make suggestions for improvement in profitability or operating position of the selected companies. The present study is made for the period of five years from 2015-16 to 2019-20.Five companies were selection. Four ratios were used in this study: net profit ratio, gross profit ratio, material cost ratio and factory overhead ratio. To test hypothesis ANOVA was used. The major findings of this study indicate that there are no significant difference in various profitability ratios and operating ratios of selected chemical companies during the study period. Based on the data interpretation, the comparison of all the selected five chemical companies' the ratios that have been concluded in this study indicate that the Thirumalai Chemical Ltd. is in better position than other selected chemical company because its average of the selected ratio is 14.829 which is higher than the other selected chemical companies. So Thirumalai Chemical Ltd. is performing best among the selected chemical companies.
\end{abstract}

Keywords: Profitability, Financial, Operating ratio, Performance, and Improvement.

\section{Introduction}

Profit is the different between revenue and expenses over a period, usually, one year. Profitability ratios are to measure the operating efficiency of the company. Besides management, lenders and owners of the company are interested in the analysis of the profitability of the firm. If profits are adequate, there would be no difficulty for lenders to get payment of interest and repayment of principal. Owner want to get require rate of return on investment. The finance manager should evaluate the efficiency of the company, in terms of profits. So, profit is important to everyone associated with the firm while the operating ratio shows the efficiency of a company's management by comparing the total operating expenses of a company to net sales. The operating ratio shows how efficient a company's management is at keeping costs low while generating revenue or sales. The smaller the ratio, the more efficient the company is at generating revenue vs. total expenses. 
Investment analysts have many ways of analyzing company performance. Because it concentrates on core business activities, one of the most popular ways to analyze performance is by evaluating the operating ratio. Along with return on assets and return on equity, it is often used to measure a company's operational efficiency. It is useful to track the operating ratio over a period of time to identify trend in operational efficiency or inefficiency. An operating ratio that is going up is viewed as a negative sign, as this indicates that operating expenses are increasing relative to sales or revenue. Conversely, if the operating ratio is falling expenses are decreasing, or revenue is increasing, or some combination of both. A company may need to implement cost controls for margin improvement if its operating ratio increases over time. (AM Abdukareem, 2020)

\section{Literature review}

Adhegaonkar Vikas (2012), Determinants of Capital Structure: A Case of Indian Chemical Industry, in this paper company has selected by convenience sampling has used to select the sample; the period of the study is 2006 to 2011. Size, profitability, tangibility, non-debt tax shield, growth in asset, liquidity and interest coverage ratio has used to analyze their linear relationship with capital structure. Convenience sampling has used to select the sample. Statistical techniques like correlation, multiple regressions an ANOVA is used to test the hypothesis. A result shows that tangibility, non-debt tax shield and interest coverage ratio has linear relationship and rest variable has nonlinear relationship with capital structure. ANOVA shows the overall model is good. Angelin S. Kiruba and S. Vasantha (2019), The Influence of Profit Earning (PE) ratio in share price using the Earning per Share (EPS), Dividend per Share (DPS) and Profit Earning Ratio. Z-Stat, T-state and AIC test are used for analysis of impact of share price. The financial data used from 2013-2017. Results declared selected ratios are creating the smaller impact when comparing with other ratios. Elumalai ET all (2014), Growth and Productivity Analysis of Chemical Industry in Tamilnadu, the main purpose of this paper is to analyze the growth and productivity in Chemical industry I Tamilnadu for the period of pre and post liberalization i.e. 1980-81 to 2001-02. The labor productivity was better and the capital productivity was low during pre and post liberalization. It is necessary that both public and private investment should be enhanced in chemical research and technology for sustaining productivity growth in the long run.Kapil Shrimal and Hanuman Prasad (2015), Profitability ratio creating the effect on the capitalization decision of industries in India. Return on Capital employed, Earning per share, Dividend Payout Ratio, Net Profit Margin, Return on Equity and return on net worth are considered as the variables which are influencing the capitalization of the company. The five year data from 2009-2014 in the 23 infrastructure company has been used. The regression and correlation analysis done on the study. From that, it was understood there is a relationship in capitalization due to the variable of Return on capital employed and earnings per share. Sampathkumar. T (2006), Productivity in Indian Chemical sector an intra sect oral analysis, in this study researcher divided the study period into two phases were pee reform period (1980-81 to 1990-91) and post reform period (1991-92 to 2001-02) such as a classification of period was essential to find the impact of economic reforms on the improvements of the total productivity. The study has been estimated the trend in growth of 
total productivity of Indian Chemical Industry at the sub-sect oral level and the study sources took from ASI and RBI publications. The study also estimated TFP (total-factor productivity) using Tran slog model. The result showed that TFPG (total-factor productivity growth) of drugs and pharmaceutical paints and varnishes Basic chemical and dyes and dyestuff industries are better in the period of post reform as the change is significance and the decline in extent of negative productivity growth. It suggested that while making policy decisions based on aggregates, the consideration of intra-sect oral variation would provide more decisions that are valuable.

\section{Objectives of the study}

- To evaluate the profitability performance and operating position of selected chemical companies in India.

- To evaluate financial performance of selected chemical companies in India.

- To evaluate which company is performing the best.

- To make suggestions for improvement in profitability or operating position of the selected companies.

\section{Data Collection}

This study is based on the secondary data taken from published annual reports of selected companies like Tata Chemicals Ltd., Thirumalai Chemicals Ltd., Supreme Petrochem Ltd., Gujarat Flurochemicals and Himadri Speciality Chemicals Ltd. other information related to companies has taken from various books, journals, official websites and net sources. Have also been used for better reliability. Options expressed in business standard, Accounting literature, annual report and different publication are used in this study.

\section{Data Analysis}

\section{Profitability Ratios}

\subsection{Net Profit Ratio}

It measures the relationship between net profit and sale of the business. Depending on the concept of net profit it can be calculate as:

$$
\text { Net Profit Ratio }=\frac{\text { Net Profit }}{\text { Sales }} \times 100
$$


Table No.1 .Profitability Ratio Analysis of Net Profit Ratio

\begin{tabular}{|c|c|c|c|c|}
\hline Year & Net Profit & Sales & $\begin{array}{c}\text { Net Profit } \\
\text { Ratio }\end{array}$ & Trend \\
\hline $\mathbf{2 0 1 5 - 1 6}$ & 917 & 14,872 & 6.17 & 100 \\
\hline $\mathbf{2 0 1 6 - 1 7}$ & 1,150 & 10,346 & 11.16 & 173.09 \\
\hline $\mathbf{2 0 1 7 - 1 8}$ & 1,510 & 10,269 & 14.70 & 238.25 \\
\hline $\mathbf{2 0 1 8 - 1 9}$ & 1,063 & 10,336 & 10.28 & 166.61 \\
\hline $\mathbf{2 0 1 9 - 2 0}$ & 1,032 & 10,356 & 9.97 & 161.59 \\
\hline Minimum Level & 917 & 10,269 & 6.17 & - \\
\hline Maximum Level & 1,510 & 14,872 & 14.70 & - \\
\hline Average Level & 1,134 & 11,236 & 10.46 & - \\
\hline
\end{tabular}

(Sources: From Annual Report of Tata Chemicals From the year 2015-16 to 2019-20)

\section{Graphical Presentation .1}

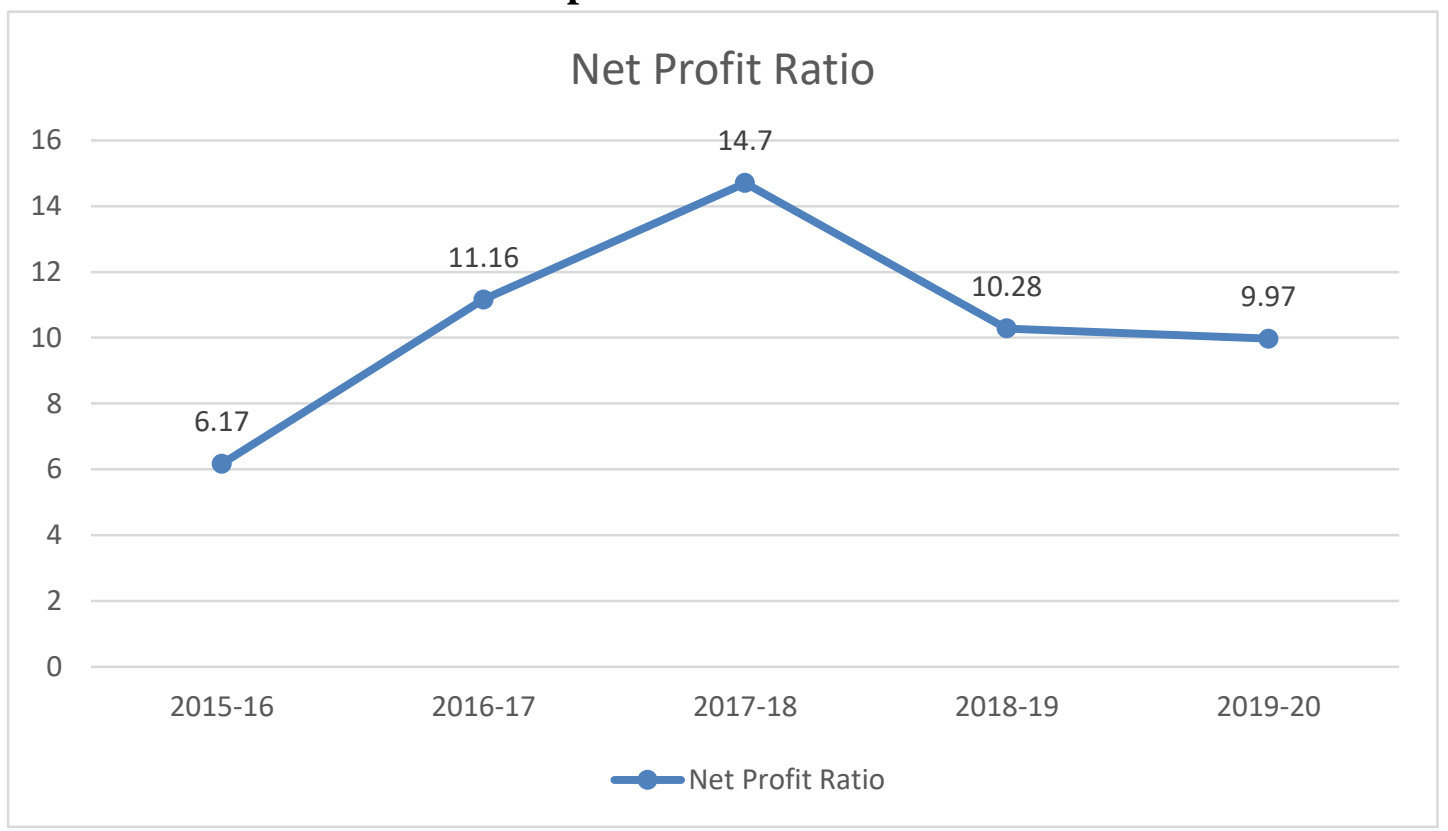

\section{Analysis}

In above the table no. 1 is about Profitability Ratio analysis of Net profit ratio during the year 2015-16 to 2019-20. The trend shows that Net profit ratio is in fluctuation trend. The minimum Net profit ratio is 6.17 in the year 2015-16. The maximum Net profit ratio is 14.70 in the year 2017-18. The average Net profit ratio was found that, 10.46.

\subsection{Gross Profit Ratio}

It measures the percentage of each sale in rupees remaining after payment for the goods sold.

$$
\text { Gross Profit Ratio }=\frac{\text { Gross Profit }}{\text { Sales }} \times 100
$$


63 | International Journal of Scientific and Management Research 4(8) 59-68

Table No 2. Profitability Ratio Analysis of Gross Profit Ratio

\begin{tabular}{|c|c|c|c|c|}
\hline Year & Gross Profit & Sales & $\begin{array}{c}\text { Gross Profit } \\
\text { Ratio }\end{array}$ & Trend \\
\hline $\mathbf{2 0 1 5 - 1 6}$ & 674.88 & 14,872 & 4.54 & 100 \\
\hline $\mathbf{2 0 1 6 - 1 7}$ & 736.77 & 10,346 & 7.12 & 156.83 \\
\hline $\mathbf{2 0 1 7 - 1 8}$ & 628.91 & 10,269 & 6.12 & 134.80 \\
\hline $\mathbf{2 0 1 8 - 1 9}$ & 603.08 & 10,336 & 5.83 & 128.41 \\
\hline $\mathbf{2 0 1 9 - 2 0}$ & 614.42 & 10,356 & 5.93 & 130.62 \\
\hline Minimum Level & 603.08 & 10,269 & 4.54 & - \\
\hline Maximum Level & 736.77 & 14,872 & 7.12 & - \\
\hline Average Level & 651.61 & 11,236 & 5.91 & - \\
\hline
\end{tabular}

(Sources: From Annual Report of Tata Chemicals From the year 2015-16 to 2019-20)

Graphical Presentation .2

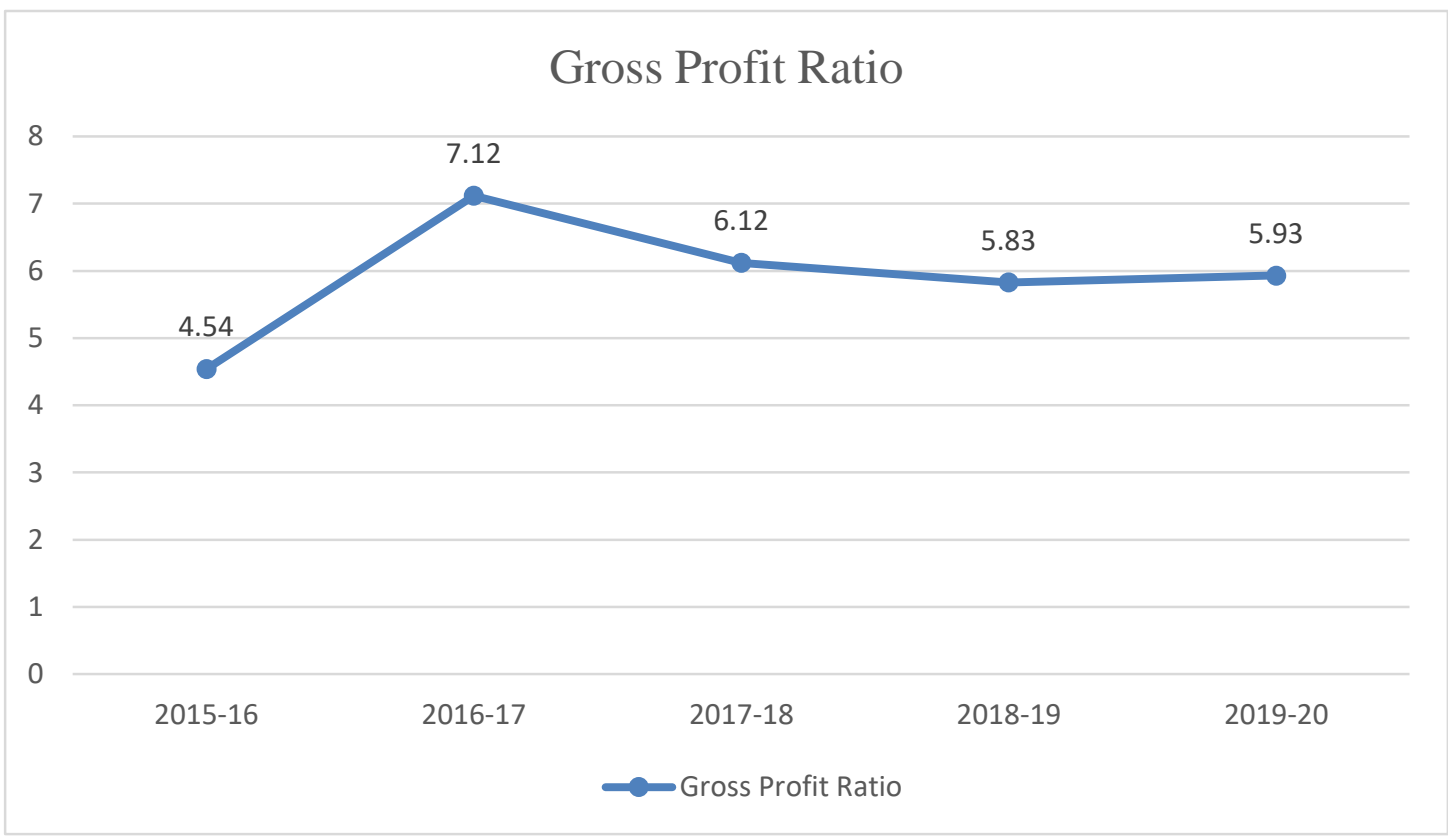

\section{Analysis}

In the above table no. 2 is about Profitability Ratio analysis of gross profit ratio during the year 2015-16 to 2019-20.The trend shows that Gross profit ratio is in fluctuation trend. The minimum gross profit ratio is 4.54 in the year 2015-16. The maximum gross profit ratio is 7.12in the year 2016-17. The average gross profit ratio was found that, 5.91.

\section{Operating Ratios}

\subsection{Material Cost Ratio}

Material cost is the cost of material used to manufacture a product or provide a service. Excluded from the material cost is all indirect materials.

$$
\text { Material Cost Ratio }=\frac{\text { Material Consumed }}{\text { Sales }} \times 100
$$


64 | International Journal of Scientific and Management Research 4(8) 59-68

Table No .3 Operating Ratio Analysis of Material Cost Ratio

\begin{tabular}{|c|c|c|c|c|}
\hline Year & $\begin{array}{c}\text { Material } \\
\text { Consumed }\end{array}$ & Sales & Material Cost & Trend \\
\hline $\mathbf{2 0 1 5 - 1 6}$ & 2867.69 & 14,872 & 19.28 & 100 \\
\hline $\mathbf{2 0 1 6 - 1 7}$ & 1314.79 & 10,346 & 12.71 & 65.92 \\
\hline $\mathbf{2 0 1 7 - 1 8}$ & 1390.56 & 10,269 & 13.54 & 70.23 \\
\hline $\mathbf{2 0 1 8 - 1 9}$ & 1773.73 & 10,336 & 17.16 & 89 \\
\hline $\mathbf{2 0 1 9 - 2 0}$ & 1844.23 & 10,356 & 17.81 & 92.38 \\
\hline Minimum Level & 1314.79 & 10,269 & 12.71 & - \\
\hline Maximum Level & 2867.69 & 14,872 & 19.28 & - \\
\hline Average Level & 1838.20 & 11,236 & 16.10 & - \\
\hline
\end{tabular}

(Sources: From Annual Report of Tata Chemicals From the year 2015-16 to 2019-20)

Graphical Presentation.3

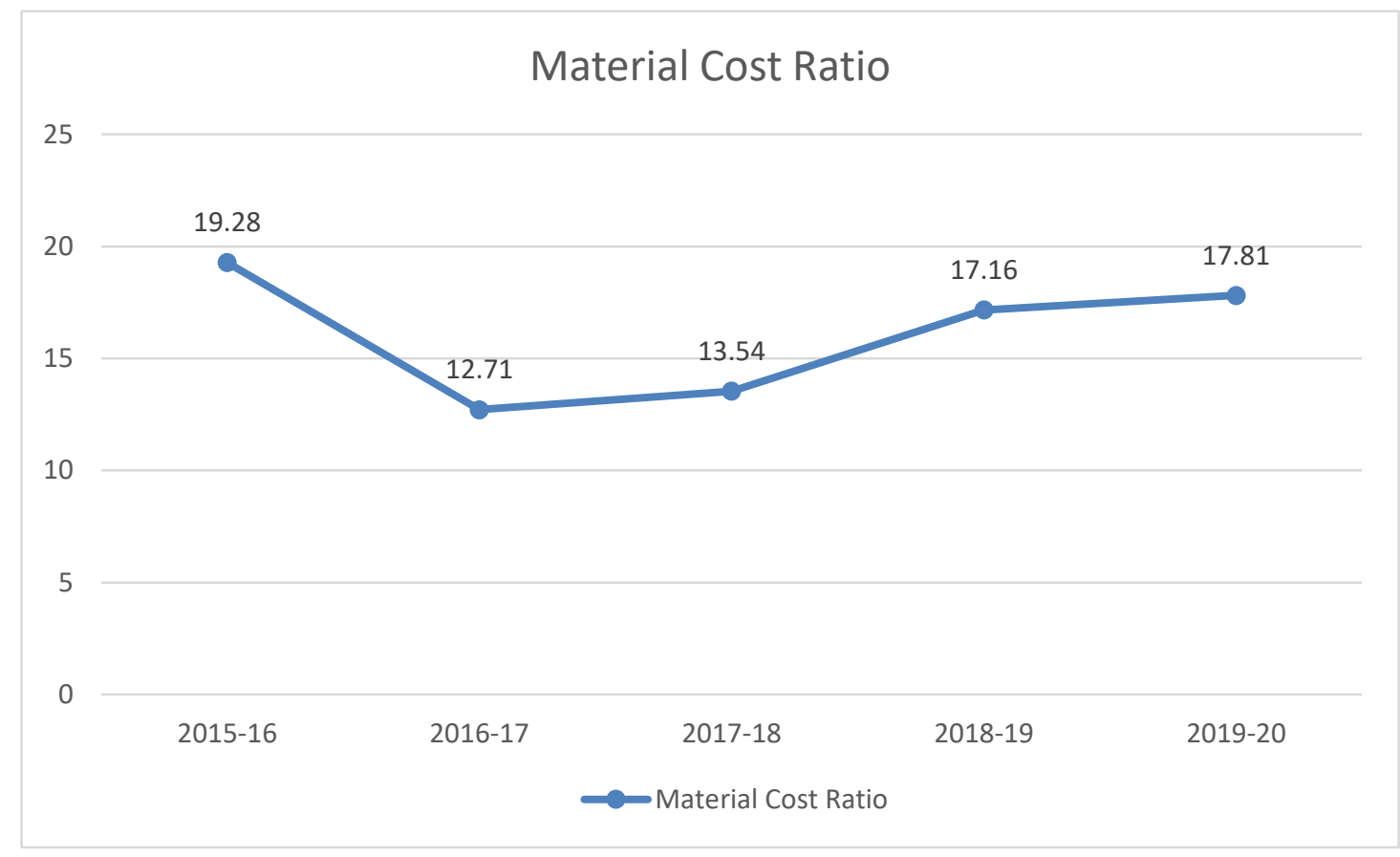

\section{Analysis}

As the above table no. 3 is about Operating Ratio analysis of Material Cost Ratio during the year 2015-16 to 2019-20.The trend shows that Material Cost Ratio is in fluctuating trend. The maximum Material Cost Ratio is 19.28 in the year 2015-16.The minimum Material Cost Ratio is 12.71 in the year 2016-17.The average Material Cost Ratio was found that, 16.10.

\subsection{Factory Overhead Ratio}

Factory overhead is how much it costs to produce a company's products, not the labor and materials it takes to directly create the widget.

$$
\text { Return on Shareholdes Fund }=\frac{\text { Factory Expenses }}{\text { Sales }} \times 100
$$


65 | International Journal of Scientific and Management Research 4(8) 59-68

Table no .4 Operating Ratio Analysis of Factory Overhead Ratio

\begin{tabular}{|c|c|c|c|c|}
\hline Year & $\begin{array}{c}\text { Factory } \\
\text { Expenses }\end{array}$ & Sales & Factory O/H Ratio & Trend \\
\hline $\mathbf{2 0 1 5 - 1 6}$ & 463.14 & 14,872 & 3.11 & 100 \\
\hline $\mathbf{2 0 1 6 - 1 7}$ & 387.13 & 10,346 & 3.74 & 120.26 \\
\hline $\mathbf{2 0 1 7 - 1 8}$ & 355.19 & 10,269 & 3.46 & 111.25 \\
\hline $\mathbf{2 0 1 8 - 1 9}$ & 383.50 & 10,336 & 3.71 & 119.29 \\
\hline $\mathbf{2 0 1 9 - 2 0}$ & 417.65 & 10,356 & 4.03 & 129.58 \\
\hline Minimum Level & 355.19 & 10,269 & 3.11 & - \\
\hline Maximum Level & 463.14 & 14,872 & 4.03 & - \\
\hline Average Level & 401.44 & 11,236 & 3.61 & - \\
\hline
\end{tabular}

(Sources: From Annual Report of Tata Chemicals From the year 2015-16 to 2019-20)

\section{Graphical Presentation.4}

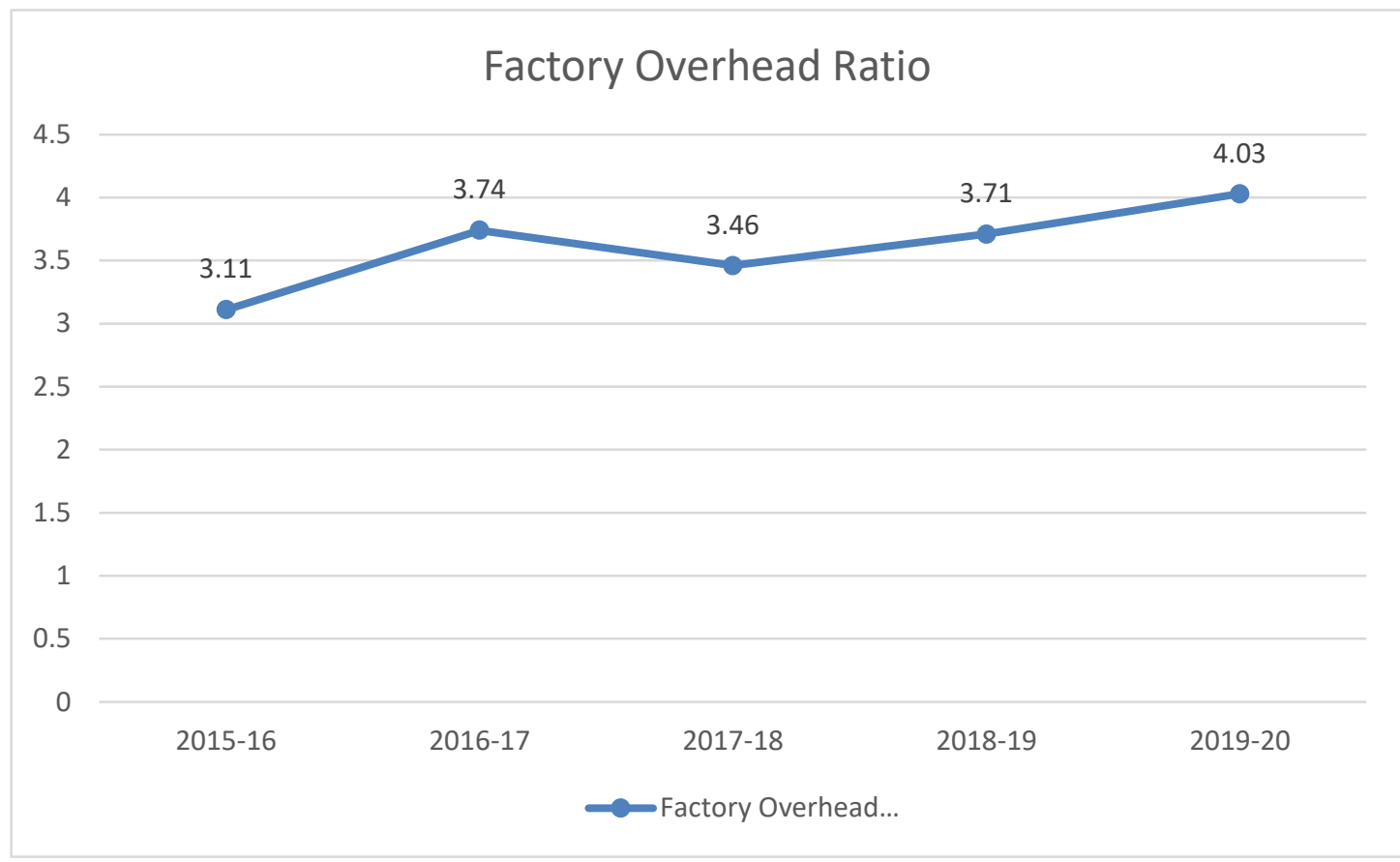

\section{Analysis}

As the above table no. 4 is about Operating ratio analysis of Factory overhead ratio during the year 2015-16 to 2019-20.The trend shows that Factory overhead ratio is in fluctuating trend. The maximum Factory overhead ratio is 4.03 in the year 2019-20.The minimum Factory overhead ratio is 3.11 in the year 2015-16.The average Factory overhead ratio was found that, 3.61 .

\section{Findings}

NET PROFIT RATIO (\%) 
Net Profit Ratio establishes relationship between net profit and sales and indicates management's efficiency in manufacturing, administrating and selling the products. This ratio is the overall measures of the firm's ability to turn each rupee sales into net profit. This ratio also indicates the firm's capacity to withstand adverse economic conditions. Firm with a high net profit ratio would be in an advantageous position to survive in the face of falling selling prices, rising costs of production or declining demand for the production or declining demand for the product. In Tata Chemicals Limited if we compare the gross profit of company for last five year so we get a higher Net Profit in the year 2017-18 14.70\% so, we can say that in 2017-18 Tata Chemicals Limited management is good. In Thirumalai Chemical Limited if we compare the Net profit of company for last five year so we get higher Net Profit in the year 2017-18 12.97\% and lower in the year 2019-20 2.12\%. In Supreme Petrochem Limited if we compare the Net profit of company for last five year so we get higher Net Profit in the year 2016-17 6.13\% and lower in the year 2018-19 1.53\%. In Gujarat Flurochemicals Limited if we compare the Net profit of company for last five year so we get higher Net Profit in the year 2018-19 23.81\% and lower in the year 2019-20 0\%. In Himadri Speciality Chemical Limited if we compare the Net profit of company for last five year so we get higher Net Profit in the year 2018-19 $13.38 \%$ and lower in the year 2015-16 0\%. All the above chemical companies we compare Net Profit Ratio in which the higher Net Profit Ratio is $23.81 \%$ in the year 2018-19 of Gujarat Flurochemicals Limited which is more than the other selected chemical companies.

\section{GROSS PROFIT RATIO (\%)}

In the Tata Chemical Limited Gross Profit is in 2015-16 4.54\%, in 2016-17 7.12\%, in 201718 6.12\%, in 2018-19 5.83\%, and 2019-20 5.93\%. In the Thirumalai Chemical Limited Gross Profit Ratio is in 2015-16 2.97\%, 2016-17 3.00\%, 2017-18 3.64\%, 2018-19 2.82\%, and 201920 2.17\%. In the Supreme Petrochem Limited Gross Profit is in 2015-16 1.07\%, 2016-17 $1.57 \%, 2017-181.17 \%, 2018-190.81 \%$ and 2019-20 1.14\%. In the Gujarat Flurochemicals Limited Gross Profit is in 2015-16 4.60\%, 2016-17 6.08\%, 2017-18 7.63\%, 2018-19 6.77\%, and in 2019-20 4.20\%. In the Himadri Speciality Chemical Limited Gross profit Ratio is for 2015-16 2.76\%, 2016-17 3.41\%, 2017-18 3.23\%, 2018-19 3.38\%, and in 2019-20 3.21\%. Gross profit ratio represents the mix trend in the Tata Chemicals limited, Thirumalai Chemical Limited, Supreme Petrochem Limited, Gujarat Flurochemicals Limited and Himadri Speciality Chemicals Limited. Gross Profit Ratio shows the access of sales over their cost. This ratio measures the efficiency of company's operations. The gross profit ratio reflects the efficiency with which management produces each unit of product. This ratio indicates the average spread between the cost of goods sold and the sales revenue. A high gross profit margin relative to the Companies average implies that the firm is able to produce at relatively lower cost. A high gross profit is a sign of good management. In Tata Chemicals Limited if we compare the gross profit of company for last five year so we get a higher Gross Profit in the year 2016-17 7.12\% so, we can say that in 2016-17 Tata Chemicals Limited management is good. In Thirumalai Chemical Limited if we compare the gross profit of company for last five year so we get higher Gross Profit in the year 2017-18 3.64\% and lower in the year 2019-20 2.17\% so the 2017-18 year is good for company. In Supreme Petrochem 
Limited if we compare the gross profit of company for last five year so we get higher Gross Profit in the year 2016-171.57\% and lower in the year 2018-19 $0.81 \%$ so the $2016-17$ year is good for company. In Gujarat Flurochemicals Limited if we compare the gross profit of company for last five year so we get higher Gross Profit in the year 2017-18 7.63\% and lower in the year 2019-20 4.20\% so the 2017-18 year is good for company. In Himadri Speciality Chemical Limited if we compare the gross profit of company for last five year so we get higher Gross Profit in the year 2016-17 3.41\% and lower in the year 2015-16 2.76\% so the 2016-17 year is good for company. The above all selected Chemical Companies we compare Gross Profit Ratio for five year in which higher gross profit ratio is 7.63 in the year 2017-18 of Gujarat Flurochemicals Limited which is more than other selected Chemical Companies.

\section{MATERIAL COST RATIO}

The average of Material Cost Ratio for the Tata Chemicals Limited is $16.10 \%$, for Thirumalai Chemical Limiter is $66.39 \%$, for Supreme Petrochem Limited is $61.44 \%$, for Gujarat Flurochemicals Limited is $34.02 \%$, and for the Himadri Speciality Chemical Limited is $67.23 \%$. From the above mentioned selected companies ratio if we are going to compare the Material Cost Ratio of the selected chemical companies then we says that $67.23 \%$ is the highest among the selected companies so we says that the Himadri Speciality Chemical Limited have a highest number of average Material Cost Ratio.

\section{FACTORY OVERHEAD RATIO}

The average of Factory Overhead Ratio for the Tata Chemicals Limited is $3.61 \%$, for Thirumalai Chemical Limiter is $0.77 \%$, for Supreme Petrochem Limited is $0.12 \%$, for Gujarat Flurochemicals Limited is $1.34 \%$, and for the Himadri Speciality Chemical Limited is $0.92 \%$. From the above mentioned selected companies ratio if we are going to compare the Factory Overhead Ratio of the selected chemical companies then we says that $3.61 \%$ is the highest among the selected companies so we says that the Tata Chemicals Limited have a highest number of average Factory Overhead Ratio.

\section{Conclusion}

After the study researcher has been conclude on the basis of available data and the hypothesis testing that Net Profit Ratio of selected chemical companies during study period has no difference. It means that the level of Net Profit ratio among selected chemical companies during the study period having equality. On the contrary Gross Profit Ratio, Material Cost Ratio and Factory Overhear Ratio having Null-Hypothesis $\left(\mathrm{H}_{0}\right)$ Rejected. It means that working level of selected chemical companies during the study period is equal.

\section{References}

1) Vikas, A. (2012). Determinants of Capital Structure: A Case of Indian Chemical Industry. Global Jurnol for Reasearch Analysis.

2) Abdulkareem, A. M. (2020). Profitability Performance of HDFC Bank and ICICI Bank: An Analytical and Comparative Study. Global Journal of Management and Business Research. 
3) Abdulkareem, A. M., \& Nagvadiya, B. R. (2021). An Analytical Study of Profitability and Liquidity Postions of Selected Life Insurance Companies in India. International Journal of Finance and Banking Research, 7(2), 28.

4) Vasantha, A. S. (2019). The Influence of Profit Earning (PE) ratio in share price using the Earning per Share (EPS), Dividend per Share (DPS) and Profit Earning Ratio. Adalya Journal.

5) all, G. E. (2014). Growth and Productivity Analysis of Chemical Industry in Tamilnadu. IOSR Journal of Economics and Finance.

6) Hanuman Prasad, K. S. (2015). Profitability ratio creating the effect on the capitalization decision of industries in India. lobal Journal for Research Analysis.

7) T, S. (2006). Productivity in Indian Chemical sector an intra sectoral analysis. Mumbai: Sammekasha Trust. 